DOI: http://dx.doi.org/10.33846/hn21107

http://heanoti.com/index.php/hn

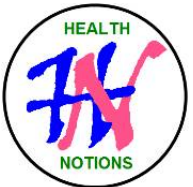

RESEARCH ARTICLE

URL of this article: http://heanoti.com/index.php/hn/article/view/hn21107

\title{
The Effect of Endorphin Massage on the Intensity of Pain in the Normal Primipara Mother in BPS Ririn Dwi Agustin Jombang
}

\author{
Hidayatun Nufus ${ }^{1(\mathrm{CA})}$ \\ ${ }^{1(\mathrm{CA})}$ Diploma III of Midwifery, STIKes ICME Jombang; hidayatunnufus77@gmail.com \\ (Corresponding Author)
}

\begin{abstract}
Background: Maternal primipara at Connecticut's average of 17 per month primipara mothers feel very great pain in stage I. The mother felt a severe pain and anxiety. Purpose: To know the influence of endorphin massage to stage I pain intensity of normal childbirth mother primipara at BPS Ririn Dwi Agustin Jombang. Methods: This research utilized quasi experimental design, the design used was posttest only control group design. Respondents were all childbirth mothers (primipara) at Juny-August 2018, selected by concecutive sampling technique. Results: Childbirth pain at most control group experience severe pain as many as 10 people $(66.7 \%)$. Respondents who experience medium pain as many as 4 people $(26.7 \%)$, and very severe pain as many as 1 person (6.7\%). Childbirth pain at most treated group experience mild pain as many as 9 people $(60.0 \%)$. Respondent who experience medium pain as many as 4 people $(26.7 \%)$, and severe pain as many as 2 people $(13.3 \%)$. The p-value of hypothesis testing was 0.000. Conclusion: There is influence of endorphin massage to stage I pain intensity of normal childbirth mother primipara ( $\mathrm{p}$ value $=0,000<0,05$ ).
\end{abstract}

Keywords: endorphin massage; stage I pregnancy; pain intensity

\section{INTRODUCTION}

Childbirth is the process of expelling the baby marked by contractions in the uterus, causing pain during the unborn baby. Women who undergo vaginal delivery always experience pain during childbirth, especially during the active phase of 1st stage vaginal labor. Labor pain is a physiological process that occurs in the muscle walls of the uterus naturally contract to open the cervix so that the baby's head pushes towards the pelvis. Contraction of the uterine muscles causes the uterine muscles to become hypoxic where the stretched cervix and the pain in the first stage of labor caused by contractions of the uterine muscles, hypoxia of the contracted muscles, the stretch of the cervix, lack of blood supply to the uterine body and lower segments a stretched uterus. Pain causes the lower thoracic sensory nerves, spinal nerves T11-12, upper lumbar, and sympathetic nerves, where the nerves run from the periphery through the spinal cord, brainstem, thalamus, and cerebral cortex (Antik, 2017). According to Nightingale's theory, human needs are holistic physiological needs, psychological, social, and spiritual needs that are healthy and unhealthy. This holistic approach is applied, among others, complementary therapies combined with conventional medical treatment. One type of complementary therapy that has been by literature to reduce pain intensity through physiological, psychological, social, and spiritual mechanisms is endorphin massage. Several studies have shown the physiological and psychological benefits of foot massage. One of the physiological effects of foot massage is reducing blood pressure. Hayes and Cox's shows that foot massage has reduced blood pressure, heart rate, and respiratory rate. Also, foot massage decreases Mean Arterial Pressure (MAP), heart rate, and respiratory rate as well as increases oxygen saturation (Rahmawati, 2013).

Massage has a positive effect on women experiencing maternal pain by reducing stress hormones and low fetal activity. After the endorphins, massage treatment mother had less anxiety, leg and back pain, and 
fewer obstetric complications while the newborn was doing well. Massage therapy increases serotonin and decreases cortisol and depression. Additionally, serotonin was to reduce leg and back pain. Massage therapy aims to increase dopamine and ultimately reduce norepinephrine and anxiety. Massage can be an effective intervention for mothers who bear to decrease the pain (Supliani, 2017).

Endhorpine massage is a light touch for relaxation and pain reduction. Therefore, this endorphin massage can be on mothers who are experiencing severe pain. Through a labor companion touch, causing a feeling of calm and relaxation, eventually, the heart rate and blood pressure become normal. Management of pain in delivery mothers needs attention from helpers so that mothers who give birth avoid labor shock that can cause postpartum blouses in the mother (Mander, 2012).

The maternal mortality rate (MMR) in Jombang Regency in 2017 was 149.68 per 100,000 live births, this figure was obtained from the number of maternal deaths of 28 people based on reports from districts/cities of 18,707 live births. With details of 10 maternal deaths during pregnancy, 3 at the time of delivery and 15 during childbirth (dinkes.jombangkab.go.id. 2017)

One way of non-pharmacological management to reduce labor pain is with endorphin massage. Endorphin Massage is a light touch/massage therapy that is quite important to pregnant women. It starts from the first time until the time of delivery. It is because massage stimulates the body to release endorphin compounds which are pain relievers and can create a feeling of comfort (Kuswandi, 2011, p. 53).

So far, endorphins are known as substances that have many benefits. Some of them are growth and sex hormones productions, controlling pain and persistent aches, controlling feelings of stress, and boosting the immune system. Endorphins in the body can trigger various activities, such as deep breathing, relaxation, and meditation (Kuswandi, 2011, p. 59).

The obstetrician, Constance Polinsky, was moved to use endorphins to reduce or relieve pain in mothers who are about to give birth. Endorphin Massage was created touch and light massage technique, which can normalize heart rate and blood pressure, and improve the relaxed state in the pregnant woman's body by triggering a feeling of comfort through the skin surface. It is evident from the results of research that this technique can increase the release of oxytocin, a hormone that facilitates childbirth (Mongan, 2009, p.127).

This is also supported by the research of Melyana, et al. (2009) entitled the effect of the hypnobirthing method on pain during the first stage of normal delivery at BPS Semarang city. The results show that most of the respondents experienced severe pain intensity is $70 \%$, and mild pain is $30 \%$. In the group given hypnobirthing, most of the respondents experienced mild pain by $66 \%$, moderate pain by $27 \%$, and severe pain by $7 \%$.

This is also supported by the results of Marfuah's (2010) research. The title difference in the intensity of pain during the first stage of normal delivery in primiparous mothers who are given hypnotherapy at BPS Yohana and Sumarni Semarang. The results showed that the group was given hypnotherapy with $40 \%$ severe pain intensity, $53.3 \%$ moderate pain, $6.7 \%$ mild pain. The group that feels was $66.7 \%$ painless, $30 \%$ moderate pain, and $3.3 \%$ mild pain.

The preliminary survey results at BPS Ririn Dwi Agustin Jombang obtained data on primiparous maternal at BPS Ririn Dwi Agustin Jombang an average of 17 per month cases of primiparous mothers felt very severe pain during the first stage. Labor pain is increasing, especially during the first stage. Even primiparous mothers said they could not stand the pain they felt. When the mother felt very pain and heightened anxiety, it could result in trauma to both the mother and the fetus. The BPS does not yet provide non-pharmacological therapies such as Endorphin Massage to pregnant women during childbirth, so mothers continue to feel pain during childbirth.

Based on the description of the background, the researcher is interested in conducting a study with the title "The Effect of Endorphin Massage on the Intensity of the First Stage of Normal Childbirth of Primipara at BPS Ririn Dwi Agustin Jombang."

\section{METHODS}

This study used a quasi-experimental quantitative research design, with the design used was posttest only control group design. The population and sample of this study were all primiparous mothers at BPS Ririn Dwi Agustin Jombang in July 2011 as many as 30 people with consecutive sampling technique. The research instruments were: questionnaire, Visual analog scale, Endhorphine massage, and Guide to Endhorphine massage.

Univariate analysis is an analysis that analyzes each variable from the research results. After data

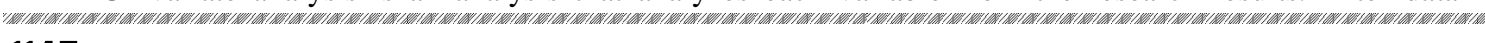
1155 | Publisher: Humanistic Network for Science and Technology 
collection is carried out, the data is analyzed using descriptive statistics to obtain tabulations, minimum, maximum, and mean by entering all the data then processed statistically descriptive to report the results in the form of the distribution of each variable. (Swarjana, 2015, p.51).

Bivariate data analysis is an analysis that is carried out by more than two variables (Swarjana, 2015, p. 51). To determine the effect of pain intensity with the independent t-test with a significance level of $=0.05$. Before conducting the t-test, the data normality test was carried out with Shapiro Wilk. The results of the normality test of this study obtained a p-value of 0.509 and 0.506 so that the data were normally distributed (P value> 0.05). Because the data is normally distributed, it uses the independent t-test.

The interpretation value in the bivariate analysis if the p-value $<0.05$ means that Ha is accepted, so there is an effect of endorphin massage on the intensity of normal labor pain. If the p-value> 0.05 means that $\mathrm{Ha}$ is rejected, so there is no effect of endorphin massage on the intensity of pain during the first stage of normal labor.

\section{RESULTS}

Age

The results of the study in the control group and the treatment group obtained age data which is as below.

Table 1. The distribution of respondents based on age in the control group and treatment group at BPS Ririn Dwi Agustin Jombang in 2018

\begin{tabular}{lcccc}
\hline Age & \multicolumn{2}{c}{ Control } & \multicolumn{2}{c}{ Treatment } \\
\cline { 2 - 5 } & $\mathrm{f}$ & $\%$ & $\mathrm{f}$ & $\%$ \\
\hline$<20$ year & 0 & 0 & 0 & 0 \\
$20-35$ year & 15 & 100 & 15 & 100 \\
$>35$ year & 0 & 0 & 0 & 0 \\
\hline total & 15 & 100 & 15 & 100 \\
\hline
\end{tabular}

Based on table 1, it is known as the age of respondents in the control group was 20-35 years old as many as 15 people (100\%). The respondents, $20-35$ years old in the treatment group $(100 \%)$.

\section{Labor Pain} in table 2.

The results of the study in the control group and the treatment group obtained labor pain data which is

Table 2. Distribution of respondents based on labor pain in the control group and treatment group at BPS Ririn Dwi Agustin Jombang in 2018

\begin{tabular}{lllcc}
\hline Labor pain & Control & \multicolumn{3}{c}{ Treatment } \\
\cline { 2 - 5 } & $\mathrm{f}$ & $\%$ & $\mathrm{f}$ & 0 \\
\hline No pain & 0 & 0 & 0 & 60 \\
Mild pain & 0 & 0 & 9 & 26,7 \\
Moderate pain & 4 & 26,7 & 4 & 13,3 \\
Severe pain & 10 & 66,7 & 2 & 0 \\
Very severe pain & 1 & 6,7 & 0 & 100 \\
\hline Total & 15 & 100 & 15 & \\
\hline
\end{tabular}


Based on table 2, it is known as the labor pain of respondents in the control group mostly experienced severe pain as many as 10 people $(66.7 \%)$. Respondents who experienced moderate pain were 4 people $(26.7 \%)$, and very severe pain was 1 person $(6.7 \%)$. Most of the respondents in the treatment group experienced mild pain as many as 9 people $(60.0 \%)$. Respondents who experienced moderate pain were 4 people $(26.7 \%)$ and severe pain were 2 people $(13.3 \%)$.

\section{The Effect of Endorphin Massage on the Intensity of First Stage Normal Childbirth of Primipara Mother at BPS Ririn Dwi Agustin Jombang}

Statistically, detect normality can be done by using the Shapiro Wilk test. The p-value in the control group pain intensity was 0.509 , and the p-value in the treatment group was 0.506 . This result means that the data distributed normally because the p-value was more than 0.05 . After the data distributed normally, the data tested statistically using the independent samples t-test.

Table 3. The Effect of Endorphin Massage on the Intensity of Stage I Normal Childbirth of Primipara Mother at BPS Ririn Dwi Agustin Jombang in 2018

\begin{tabular}{cccccc}
\hline Labor pain intensity & S & Mean & SD & SE & p-value \\
\hline Control Group & 15 & 7,40 & 1,502 & 0,388 & 0000 \\
\hline Treatment group & 15 & 3,80 & 1,821 & 0,470 & \\
\hline
\end{tabular}

Based on table 3, it is known that $\mathrm{p}$ value $=0.000$, this shows that there is an effect of endorphin massage on the intensity of pain during the first stage of normal delivery of primiparous mothers at BPS Ririn Dwi Agustin Jombang in 2018 that there is $(\mathrm{p}<0.05)$.

\section{DISCUSSION}

\section{Respondent Characteristic}

Based on the results of the study, it can be seen that the age of respondents in the control group is 20-35 years old as many as 15 people (100\%). The results of the study in the treatment group showed that the age of the respondents in the treatment group was 20-35 years old as many as 15 people (100\%). The results of this study indicate that the age of the respondents is in the category of healthy reproduction. Respondents are ready to face childbirth because their reproductive organs are ready to accept conception.

This is by the theory of Manuaba (2000, p. 133), namely that mothers who give birth at the reproductive age of the reproductive organs are ready and the mother is ready to face pregnancy so that they can respond to the labor pain they feel.

Age characteristics of respondents can affect the perceived labor pain, where the younger the pregnant woman is, the less ready she is to accept a pregnancy, the resulting response will be negative. This is by Siyoto's (2015, p.63) theory, that age has a relationship to experience with a health problem or disease and decision making. Someone older will be able to respond to the stressors faced than someone younger.

\section{Labor Pain}

It is known as the labor pain of respondents in the control group who experienced severe pain as many as 10 people $(66.7 \%)$. Respondents felt that childbirth was excruciating pain and felt the heat radiating to the spine. In the control group, they did not get endorphin massage, there are 4 people $(26.7 \%)$ who experienced moderate pain. The mother may be ready to face the labor process psychologically, but the mother is more confident and not afraid to face childbirth.

The results of the study in the treatment group showed that most of the labor pain data experienced mild pain as many as 9 people $(60.0 \%)$. This shows that respondents who are given endorphin massage can release oxytocin so that in labor the mother feels calm and is not afraid in the face of childbirth. Even though the respondents had been given endorphin massage, there were still 2 respondents who experienced pain (13.3\%). This is possible because the pain felt is subjective and the respondent's perception of pain is different.

Labor pain that occurs in the respondent is an unpleasant feeling which is an individual response that

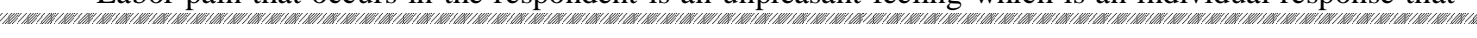


accompanies the delivery process. The pain experienced by respondents was due to physiological changes in the birth canal and uterus. This result is supported by Bandiyah's theory (2009, p.81), that labor pain is caused by cervical dilation, hypoxia of the uterine muscles during contraction, uterine ischemia, and stretching of the lower uterine segment, and compression of the nerves in the cervix.

The pain felt by respondents varied in the control group and the treatment group. Pain that occurs due to stress in the face of pregnancy can stimulate excessive uterine contractions. Uncontrolled uterine contractions will deliver pain during childbirth. The stimulation of the large nerves will increase the mechanism of the activity of the substance. The results in the closing of the mechanism, so T cell activity is inhibited and causes the delivery of stimuli to be obstructed, and causes the delivery of stimuli to be obstructed. Stimulation of small fibers will inhibit the activity of the substance and open the mechanism. Thereby stimulating $\mathrm{T}$ cell activity which in turn will deliver pain stimuli.

\section{The Effect of Endorphin Massage on the Intensity of First Stage Normal Childbirth of Primipara Mother at BPS Ririn Dwi Agustin Jombang}

Based on the results of the study, it is known that $\mathrm{p}$-value $=0.000$, this indicates that there is an effect of endorphin massage on the intensity of pain during the first stage of normal delivery of primiparous mothers at BPS Ririn Dwi Agustin Jombang in 2018 that there is ( $\mathrm{p}<0.05$ )

The mechanism of childbirth that occurs in respondents can modify and change the sensation of pain that comes before they reach the cerebral cortex, giving rise to pain perception. This is by the theory of Perry \& Potter (2005), small fibers transmit a loud pain sensation which has receptors in the form of free nerve endings in the skin and deep structures such as tendons, muscles, and internal organs. While large fibers transmit the sensation of touch, vibration, warm temperature, and subtle pressure.

One way to reduce pain in mothers who give birth is with an Endorphin massage. Endorphin massage is a non-pharmacological therapy to reduce or relieve pain in mothers who are about to give birth. This massage stimulation causes the fast-moving impulses from the peripheral nerve receptors to reach the gate first of the pain impulses traveling more slowly along the pain fibers. Then the brain receives and generally interprets sensation messages and does not receive pain messages. According to Mongan (2009, p.127) states that endorphins can increase the release of oxytocin, a hormone that facilitates labor so that it can reduce pain. Endorphine massage can regulate the production of growth and sex hormones, control pain and persistence, control feelings of stress, and boost the immune system.

The emergence of endorphins in the respondent's body can be triggered through various activities, such as deep breathing and relaxation, and meditation. Endorphin levels vary from person to person. This is what causes the respondent's pain to be different from the others. Endorphine massage can increase the release of oxytocin so that it can stimulate pain reduction. According to Brunner and Suddarth (2002, p.232), endorphins are neurotransmitters that inhibit the delivery of pain stimuli so that they can reduce pain sensation.

The results of this study were also supported by Insaffitan's (2006) research entitled "The Effect of Back Massage on First Stage Primigravida Pain of Physiological Labor (Case Study at Gajayana Hospital Malang)" supporting pain relief can be reduced by massage. The results obtained by the average pain scale of the respondents before doing massage and after massage were significantly different. The average pain scale of the respondents before doing massage was 12.31 and after doing massage the average pain scale was 4.69.

\section{CONCLUSION}

Based on the results, there is an effect of endorphin massage on the pain intensity of the first stage of normal delivery of primiparous mothers at BPS Ririn Dwi Agustin Jombang.

\section{Acknowledgment}

Acknowledgment that the writers said was to Public Health Office of Jombang, that had helped in data collection, and also all of the mothers who had willing to become respondent, thus, this research could be conducted well. 


\section{REFERENCES}

1. Antik, Lusiana. Pengaruh Endhorpin Massage Terhadap Skala Intensitas Nyeri Kala I Fase Aktif Persalianan. Jurnal Ke Jurnal Kebidanan. 2017. Vol.6 No 12 April. ISSN.2089-7669

2. Asmadi. Teknik Prosedural Keperawatan : Konsep dan Aplikasi Kebutuhan Dasar Klien. Jakarta: Salemba Medika. 2008.

3. Bandiyah, S. Kehamilan, Persalinan \& Gangguan Kehamilan. Yogyakarta: Nuha Medika. 2009.

4. Brunner \& Suddarth. Buku Ajar Keperawatan Medikal Bedah. Edisi 8 Volume 3. Jakarta: EGC. 2002.

5. Harianto, M. Aplikasi Hypnosis (Hypnobirthing) Dalam Asuhan Kebidanan Kehamilan \& Persalinan. Yogyakarta: Penerbit Gosyen Publishing. 2010.

6. Hidayat, A.A. Pengantar Kebutuhan Dasar Manusia: Aplikasii Konsep dan Proses Keperawatan. Jakarta: Penerbit Salemba Medika. 2006.

7. Hidayat, A.A. Metode Penelitian Kebidanan Tehnik Analisis Data. Jakarta: Salemba Medika. 2009

8. Dinas Kesehatan Kabupaten Jombang. Jombang Health Profil 2017. Jombang: Dinas Kesehatan Kabupaten Jombang. 2017.

9. Insafitta, S. Pengaruh Masase Punggung Terhadap Nyeri Primigravida Kala I Persalinan Fisiologis (Studi Kasus di RSAB Gajayana Malang). Malang : Karya Tulis Ilmiah Tidak dipublikasikan. Jakarta: EGC. 2006.

10. Llewellyn, D. Dasar-dasar Obstetri \& Ginekologi. Edisi 6. Jakarta : Hipokrates. Manuaba, IBG. 2009.

11. Mander. Nyeri Persalinan. Jakarta: EGC. 2012.

12. Marfuah. Perbedaan intensitas nyeri kala I persalinan normal pada ibu primipara yang diberikan hypnoterapy di BPS Yohana dan Sumarni Semarang Tahun: Karya Tulis Ilmiah Tidak dipublikasikan. 2010 .

13. Melyana, dkk. Pengaruh Metode Hypnobirthing terhadap Intensitas Nyeri Kala I Persalinan Normal di BPS Kota Semarang. Semarang: Politeknik Kesehatan Semarang. 2009.

14. Mochtar, R. Sinopsis Obstetri Jilid I. Jakarta: EGC. 2003.

15. Mongan, M. Hypno Birthing: Metode Melahirrkan Secara Aman, Mudah dan Nyaman. Jakarta: PT Bhuana Ilmu Populer. 2009.

16. Notoatmodjo, S. Metode Penelitian Kesehatan. Jakarta: PT Rineka Cipta. 2005.

17. Perry dan Potter. Buku Ajar Fundamental Keperawatan Konsep, Proses dan Praktek. Edisi 4. Alih bahasa Renata Komalasari. Jakarta: EGC. 2005.

18. Prawirohardjo, S. Ilmu Kebidanan. Jakarta: Yayasan Bina Pustaka Sarwono Prawiroharjdo. 2008.

19. Profil Kesehatan Indonesia Tahun. Profil Kesehatan Indonesia Tahun 2009. Indonesia: Kementrian Kesehatan Republik Indonesia. 2009.

20. Reproduksi Wanita. Jakarta : EGC. Mander, R. Nyeri Persalinan. Cetakan I.

21. Siyoto. Dasar Metodologi Penelitian. Yogyakarta: Literasi Media Publishing. 2015.

22. Sumarah. Perawatan Ibu Bersalin (Asuhan Kebidanan Pada Ibu Bersalin). Yogyakarta: Fitramaya. 2009.

23. Swarjana, I Ketut. Metodologi Penelitian Kesehatan (Edisi Revisi). Yogyakarta: Andi Offset. 2015. 